From the Spice Islands to Cape Town: The life and times of Tuan Guru.

Shafiq Morton.

[Cape Town]: National Awqaf Foundation of South Africa, 2018. pp. 169.

ISBN 978-0-620-81195-8.

Even though Islam at the Kaap de Goede Hoop was repressed and driven underground during the jurisdiction of the Dutch United East India Company (the Verenigde Oost-Indische Compagnie, VOC) it firmly established itself among free blacks and a burgeoning underclass population of slaves. It is logical that Southeast Asian labourers, slaves, convicts and political prisoners would pass on their faith tradition to their new world. It is generally accepted that Shaykh Yusuf of Makasar who resisted the imposition of VOC rule in Banten and was subsequently exiled to the Cape with an entourage of 49 people in 1693, laid the foundations of Islam at the Cape.

For much of the time of VOC rule the Muslim faithful, when they had the opportunity, gathered clandestinely in the homes of free blacks, or surrounding forests and secluded spots on !Hoerikwaggo, the mountain in the sea. It is said that they were publicly distinguishing themselves by closely upholding the cen- tral tenets of their tradition, the manner of their dress, their social behaviour and their artisanship. It was only in 1804 during the Batavian interregnum that Muslim adherents were allowed to practice their religion openly. It is further notable that in South Africa the history of colonialism, slavery, Islam and the development of Cape Dutch (later: Afrikaans) is intertwined.

Shafiq Morton's historical study From the Spice Islands to Cape Town deals, as the subtitle indicates with "the life and times of Tuan Guru", one of the key figures in the history of Islam at the southern point of Africa. 'Abdullah Ibn Qadi 'Abd ul-Salam, later known among Cape Muslims as Tuan Guru (Grand Teacher), was born in Tidore in 1712. For much of his life he was an advisor to Sultan Jamal al-Din, the ruler of the spice revenue-funded Sultanate of Tidore on the tropical Maluku islands in the Southeast Asian archipelago.

At a time of struggle for control over the spice trade, the Sultan and several of his courtiers allegedly collaborated with the opposing English against the corporate designs of the VOC (known colloquially also as "Vergaan Onder Corruptie") (see 42-46; 49). The Dutch, in order to subvert the recalcitrant sultan's power, exiled him to Ceylon (today's Sri Lanka), and banished Tuan Guru and three other Tidorese advisors without their families "tot nadere orde" (until further instructions) initially to Batavia (today's Jakarta) and later to the Cape (49). At the age of 68, Tuan Guru landed at the Cape on board De Zeepard. As political prisoners, he and his fellow courtiers were immediately incarcerated on a bleak and windswept Robben Island, a place he referred to as Pulau Aylan. He was released a year later, during a period of an impending English attack against the Cape way station. Later, he was sentenced to the island for a further spell of banishment from 1786 to 1791.

Between 1667 and 1793 hundreds of Southeast Asian slaves and convicts were confined to the Cape as a place of enslavement and as a penal colony, as were "182 princes, emirs, advisors and imams" (11). By 1790 the Muslim community comprised 2460 persons, growing to 6000 by 1842, a third of the Cape Colony's population (12). These people were often literate and introduced to the Cape literacies different to the dominant Dutch or other European literary traditions. Tuan Guru arrived at the Cape at a time that Morton (12-13) regards as a time of "urbanisation and expansion", and in a place where the Islamic faith was suppressed even if tolerated. At the time, Islamic communal leadership operated covertly, education was neglected, and the observances of religious and cultural practices were tenuous. 
On his release from his second spell of banishment Tuan Guru played a pioneering role in organising and educating the faithful, making him "our country's first recorded urban activist" (13).

On his release Tuan Guru stayed on at the Cape, "a place of sadness" (105) and would turn his exilic loneliness, homesickness and estrangement into a force for good. As an exile of royal descent he was apparently not sentenced to hard labour and used his time to write his Ma'rifat al-Islam wa'l-Imān (The Knowledge of Islam and Faith), a manuscript consisting of 613 handwritten pages dealing with Islamic law and religious practices, written in black and red ink on folios in Arabic with translations in Malayu and Buginese (see 99-111). Early Islamic leaders and teachers regard the Ma'rifat as "the definitive text on Islam in South Africa" and the historian Achmat Davids suggested that "no other book had a more seminal influence at the Cape than this handwritten manuscript" (110).

Further, as a Hafiz ul-Qur'an, that is one who has memorised the Holy Book, Tuan Guru wrote down the entire text of the Qur'an of 6000 verses from memory, thereby formalising the local Hifz tradition of Qur'anic memorisation (60-61). The existence of the Qur'an (and a further four) to the Bible of the dominant and despised Dutch left an impression on the faithful, and its symbolism amidst religious suppression was undeniable: "We can just imagine the impact and authority of a Qur'an in the 1780s [...] Tuan Guru's Qur'ans were weighty textual declarations of social identity" (67). Today, one of Tuan Guru's handwritten Qur'ans is exhibited in the Awwal mosque in Cape Town.

On return from his second spell of imprisonment Tuan Guru, then 79, took Keijda van de Kaap as his wife, and she bore him two sons. By 1794 he was living in a place on Dorp Street in Bo-Kaap, one of two adjacent properties bought by the free black, Coridon of Ceylon. It was here that he established the first madrasah, that is, a Muslim religious school, in South Africa in 1793. By 1825 the student roll amounted to 491. For the diverse Muslim community whose adherents came from Southeast Asia, parts of Africa, several Indian Ocean islands and elsewhere, the Awwal madrasah and the mosque became the centre of their activities. Their doctrinal practices were encompassing of local and received traditions, so that Tuan Guru who died in 1807 constructed "a space within the existing socio-colonial one in which slaves and free blacks, the Cape underclass could exist" (82). The madrasah and mosque became "an inclusive institution in an exclusive colonialist society" and under his guidance "a unique Cape Town identity" developed, coalescing the diverse free black and slave community into "a recognisable group" (99).

Morton tells, for those readers interested in the underclass history of the Cape, an engrossing tale of Tuan Guru's history in Tidore, the world of his upbringing, his banishment, his supposed spiritual powers and his leadership. He spends a full chapter, Chapter 10, on the meaning of Ma'rifat al-Islam wa'l-Imān and traces the considerable impact of Tuan Guru and his descendants on life in the Cape Muslim community and the broader South African society. Through the Arabic orthography the Awwal madrasah played a pivotal role in developing an alternative communal literacy tradition that gradually changed from Malayu to Cape Dutch and gave rise to what we today know, as the Arabic-Afrikaans scribal tradition. Beginning with Tuan Guru, successive imams and Muslim leaders established the local Islamic education tradition and network of community support organisations that outlasted the Batavian, British and the early South African administrations and are still flourishing well into the 2lst century.

Morton's account is well-written and worthy of the story of a remarkable man whose legacy lives on through his writings, the religious and educational traditions he fostered and through the achievements of his many descendants. It is a welcome addition to the growing collection of biographical and historical works on underclass figures and communities.

\section{Hein Willemse}

hein.willemse@up.ac.za

University of Pretoria

Pretoria

ORCID: https://orcid.org/0000-0002-9806-4410

DOI: https://doi.org/10.17159/2309-9070/tvl.v.57il.8082 